\title{
Kuurojen ja huonokuuloisten opiskelijoiden kaksi koulutussukupolvea
}

\author{
ELINA LEHTOMÄKI
}

"Ruotsalaisten ja yhdysvaltalaisten tutkimusten mukaan kuurojen ja huonokuuloisten aikuisten koulutustaso, työllisyystilanne ja sosiaalinen asema ovat muuttuneet sukupolvesta toiseen siirryttäessä. Koulutus on ollut tärkeä tekijä sosiaalisen aseman muutoksessa. Näin ei vielä ole tapahtunut oppimisyhteiskunnan mallimaassa, Suomessa", aiheesta väitellyt Elina Lehtomäki kirjoittaa.

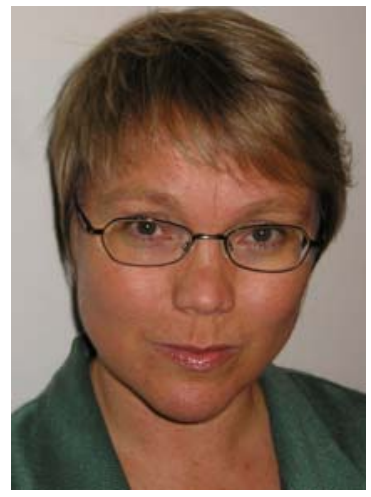

$\mathrm{K}_{\mathrm{o}}$ vaikutus ja marginalisoituminen ovat hyvin ajankohtaisia teemoja tieteessä. Marraskuussa Jyväskylän yliopistossa pidettyjen Kasvatustieteen päivien teemana oli Koulutuksen ja hyvinvoinnin kohtalonyhteys (ks. Kasvatustieteen päivät 2005). Toukokuussa 2005 Joensuun yliopistossa pidettiin monitieteinen kansainvälinen konferenssi, jossa tarkasteltiin osallistumista aikuiskasvatukseen, työssäoppimiseen ja kansalaisyhteiskuntaan (ks. Sosiologia, Margins 2005). Keskeisiä kysymyksiä olivat marginalisoituminen ja osallistumattomuus.

Tieteellisten keskustelujen lisäksi koulutuksen ja yhteiskunnan välistä vuorovaikutusta on käsitelty kahdessa tuoreessa historiikissa, Bovalliusten perintö, S. jaA. Bovalliuksen säätiö 19052005 (Ruuskanen 2005) sekä teoksessa Maahan lämpimään, Suomen viittomakielisten historia (Salmi \& Laakso 2005). Nämä julkaisut on tuotettu satavuotisjuhliin, joita viime syksynä viettivät "kuuromykkien" naisten jatkokoulutusta aikoinaan käynnistänyt Bovallius-säätiö ja viittomakielisten oikeuksia puolustava Kuurojen Liitto. Historiikeissa kuvataan sadan vuoden aikana tapahtuneita muutoksia yhteiskunnassa, koulutuksessaja vähemmistön asemassa em. järjestöjen tehtäväkenttien näkökulmasta.

Salmen ja Laakson mukaan $(2005,487)$ "lähes kaikki kuurojen elämää helpottaneet, tasavertaiseen asemaan kuulevien kanssa tähdänneet uudistukset ovat saaneet alkunsa yhteisön sisältä. Carl Oscar Malmin unelma itsenäisestä, sivistyneestäja tasavertaisesta kuurosta kansalaisesta on 2000-luvulla toteutumassa" (kursiivit minun). Nähdäkseni tämä unelma on hyvin lähellä oppimisyhteiskuntaan osallistumista, joka on ollut tutkimukseni kohde.

\section{Erityisopetus osana oppimisyhteis- kuntaa}

Olen tarkastellut perusasteen jälkeistä erityisopetusta osana oppimisyhteiskunnan kehittämistä sekä koulutuksen sosiaalista merkitystä. Lähtökohtanani on ollut Torsten Husénin (1974) määritelmä oppimisyhteiskunnasta (learning society), jossa 1) kaikilla on mahdollisuus elinikäiseen oppimiseen, 2) muodollinen koulutus koskettaa koko ikäluokkaa, 3) ei-muodollinen koulutus on keskeisessäasemassaja itseopiskelu suosittua, 4) muut sosiaaliset instituutiot ja organisaatiot tu- 
kevat koulutusta, ja se puolestaan on riippuvainen niistä. Määritelmän mukaan oppiminen ylittää perinteisesti ikäsidonnaisena pidetyn ja muodolliseen koulutukseen sidotun oppimisen rajat. Määritelmässä korostetaan koulutuksen ja yhteiskunnan yhteyksiä sekä koulutuksellista tasa-arvoa.

Tutkimukseni kannalta merkittävimpiä suunnannäyttäjiä ovat olleet Ari Antikaisen johtama tutkimushanke Koulutuksen merkitystä etsimässä ja toinen Akatemian tutkimusohjelma, Koulutuksen vaikuttavuus. Antikaisen tutkimusryhmä on lähestynyt yhteiskunnan ja koulutuksen muutoksien välisiä yhteyksiä koulutus- ja oppimiskokemusten näkökulmasta. Koulutussukupolvien kontekstiin sijoitettujen kokemusten valossa ryhmä on kuvannut, millaista elinikäinen oppiminen on käytännössä, ja selittänyt oppimisyhteiskunnan muodostumista.

Koulutuksen vaikuttavuus -tutkimusohjelma pyrki palvelemaan käytäntöä ja lisäämään edellytyksiä ennakoida tulevaisuutta siten, että koulutusjärjestelmän kyky vastata yhteiskunnan muutoksiin vahvistuu. Reijo Raivolan (2000) mukaan tutkijat ovat nykyään enemmän kiinnostuneita oppimisesta ja osaamisesta kuin muodollisesta koulutuksesta. Vuosituhannen vaihteessa on tunnustettu, että oppimista tapahtuu kaikilla elämänkulun alueilla, perheessä, työssä ja vapaaaikana sekä läpi elämän. Muodollisesta koulutuksesta on tullut itsestäänselvyys.

\section{Marginaali tutkimuskohteena laaje- nee}

$\mathrm{V}$ errattuna muuhun kasvatustieteelliseen tutkimukseen erityispedagogiikassa on toistaiseksi vähän tarkasteltu läpi elämän jatkuvaa koulutusuraa ja oppimista. Mark Priestleyn (2001; 2003) mukaan tutkijoilta on unohtunut vammaisuus läpi elämän kulkevana ilmiönä, osana elämänkulkua. Hän on korostanut historialliseen ja sosiaaliseen kontekstiin sijoitetun elämänkulun tarkastelua yhteiskunnan epäkohtien esille tuomiseksi.

Lynn Davies (2001) on todennut koulutussosiologisten marginaalien tarkastelun täydentävän yleiskuvaa koulutuksesta kyseenalaistamalla itsestäänselvyyksiä. Nähdäkseni oppimisyhteiskunnan toteutuminen (kaikille) ja koulutuksen myönteinen merkitys ovat juuri tällaisia itsestäänselvyyksiä.
Tutkimukseni tavoitteena on ollut tuoda marginaalin näkökulma oppimisyhteiskunnan kehittämiseen. Tuula Helne (2002) on tähdentänyt, että osallistujan näkökulman esiin tuominen edellyttää tutkijalta perehtymistä sosiaalisen maailman osallistumisehdoista ja osallistumisesta saatuihin kokemuksiin. Toisaalta osallistujan näkökulmaa ja kokemuksia on tarkasteltava yhteiskunnan säätelemien ja tarjoamien mahdollisuuksien ja rajoitusten kontekstissa. Marginaalin näkökulma edellyttää kokonaiskuvan hahmottamista, jota tutkimuksessani edustaa tavoitteellinen oppimisyhteiskunnan kehittäminen.

\section{Suomalaisen oppimisyhteiskunnan marginaali}

T oisen maailmansodan jälkeen suomalaisessa koulutuspolitiikassa on tavoitteellisesti pyritty kohti husénilaista oppimisyhteiskuntaa, ja koulutus on ollut oleellinen osa myönteistä yhteiskunnallista kehitystä (Antikainen 1998; Järvelä 1991; Lampinen 1998; Virtanen 2002). Koulutuksen, varsinkin erityisopetuksen, on oletettu ehkäisevän syrjäytymistä tai ratkaisevan syrjäytymisen ongelmia.

Kansainvälistä huomiota herättäneet erinomaiset oppimistulokset OECD-maiden välisissä vertailuissa ovat olleet kuin palkinto pitkäjänteisestä ja tavoitteellisesta oppimisyhteiskunnan kehittämisestä ja koulutukseen investoinnista (ks. OECD 2004; McGaw 2004; Kupari \& Välijärvi 2005). Laadukas erityisopetus on ollut yksi hyviin oppimistuloksiimme vaikuttaneista tekijöistä.

Antikaisen (1998) mukaan koulutuksen merkitys näkyy siinä, miten ihmiset ovat käyttäneet koulutusta elämässään. Siten koulutuksen pitkäkestoinen vaikuttavuus on tarkasteltavissa vasta vuosia koulutuksen jälkeen. Oppimisyhteiskuntaan osallistumisessa olennaisia ovat olleet mahdollisuudet ja inmisten kiinnostus jatkuvaan oppimiseen, opiskeluun ja kouluttautumiseen. Vastuu mahdollisuuksien tarjonnasta on ollut yhteiskunnalla; vastuu mahdollisuuksien käyttämisestä yksilöillä. Tähän liittyviä kriittisiä kysymyksiä ovat olleet koulutusmahdollisuuksien tarjonnan ja kysynnän tarkoituksenmukainen kohtaaminen jatkuvasti muuttuvassa yhteiskunnassa sekä sosiaalisten viiteryhmien vastuu tai osuus koulutuksen merkityksen rakentumisessa. 


\section{Syrjäytyminen ja marginalisoituminen}

Oppimisyhteiskunnan kehittämisen kääntöpuolena on ollut lisääntyvä syrjäytyminen ja marginalisoituminen. Daviesin (2001) mukaan koulutussosiologinen marginaalien tarkastelu täydentää yleiskuvaa koulutuksesta kyseenalaistamalla itsestäänselvyyksiä. Nähdäkseni oppimisyhteiskunnan toteutuminen (kaikille) ja koulutuksen myönteinen merkitys ovat juuri tällaisia itsestäänselvyyksiä.

Syrjäytyminen (social exclusion) ja marginalisoituminen (marginalisation) ovat läheisiä käsitteitä. Molemmat viittaavat yleisen ulkopuolelle jäämiseen, ja ne ymmärretään sosiaalisen osallistumisen (inclusion) vastakohtina. Näitä käsitteitä erottavina piirteinä Markku Jahnukainen (2001) on korostanut sosiaalisten vs. yksilöllisten tekijöiden osuutta. Hänen mukaansa syrjäytyminen tapahtuu vaiheittain. Sosiaaliset tekijät, kuten koulutus, työ ja alakulttuureihin tai viiteryhmiin kuuluminen aiheuttavat syrjäytymistä. Esimerkiksi ongelmat kotona ja koulussa saattavat johtaa heikkoon koulumenestykseen, joka puolestaan voi heikentää työmarkkina-asemaa. Mahdollisesti seuraavana vaiheena on liittyminen samankaltaista alakulttuuria edustavaan viiteryhmään (kouluttamattomat, työttömät, köyhät).

Toinen käsitteistä, marginalisoituminen ei välttämättä viittaa heikkoon sosiaaliseen asemaan.
Marginalisoitumista eivät niinkään tuota ulkoiset sosiaaliset tekijät, vaan enemmän yksilölliset valinnat ja mahdollisuudet. Marginalisoituneina Jahnukainen (2001) on nähnyt omien valintojensa vuoksi valtavirran ja yhteiskunnan päätöksenteon ulkopuolelle jääneet.

Erityispedagogisessa tutkimuksessa marginaaliin joutumista ja kuulumista on harvoin tällä tavoin kyseenalaistettu. Marginalisoituminen on otettu kuin itsestään selvänä lähtökohtana ja erityisopetuksen perusteena. Ari Antikaisen (2005) mukaan valintana koulutukseen osallistumattomuus voi myös olla menneen ajan identiteetin puolustusta; osa väestöstä elää vielä teollista eikä informaatioaikaa. Tutkimustulosteni perusteella tärkeää on kuitenkin kiinnittää huomiota osallistumismahdollisuuksiin ja -ehtoihin. Mielestäni Antikaisen käyttämä käsite koulutuksen reunalla kuvaa hyvin marginaalia.

Olen tarkastellut koulutuksen reunaa ja sosiaalisen merkityksen rakentumista yhteiskunnan tilan, koulutusmahdollisuuksien ja työelämän muutosten välisen kolmion kautta (kuvio 1):

Jälleenrakennuksen ja kasvavien koulutusmahdollisuuksien yhteiskunnassa kuuroille ja huonokuuloisille suomalaisille ammatillinen erityisopetus merkitsi ensisijaisesti ammattitaitoa ja työtä. Koulutukseltaan ja sosiaaliselta asemaltaan he eivät juurikaan erottuneet muusta väestöstä, koska ammattitaitoisesta työvoimasta oli kysyntää (kuvio 2).

KUVIO 1. Keskeisten käsitteiden väliset yhteydet

TAVOITTEELLINEN OPPIMISYHTEISKUNNAN RAKENTAMINEN

- Kaikilla mahdollisuus elinikäiseen oppimiseen

- Koko ikäluokan muodollinen koulutus

- Ei-muodollinen koulutus keskeistä ja itseopiskelu suosittua

- Muut sosiaaliset instituutiot ja organisaatiot tukevat koulutusta; koulutus puolestaan on niistä riippuvainen

KOULUTUKSEN MUUTOKSET
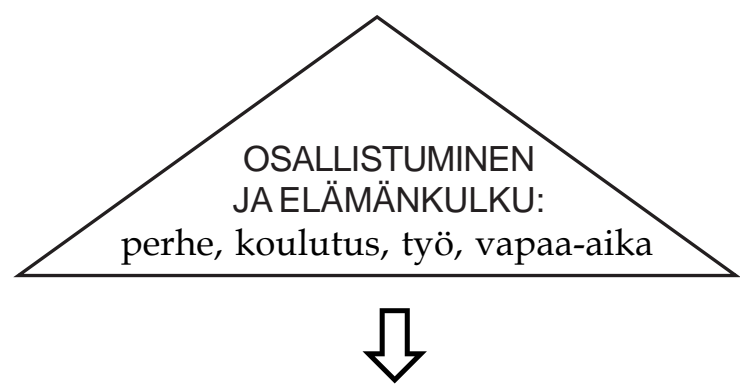

OSALLISTUJIEN KOKEMUSKOULU

TUKSEN MERKITYKSESTÄ

OMASSA ELÄMÄSSÄÄN
TYÖELÄMÄN MUUTOKSET 
KUVIO 2 Koulutuksen merkitys erityisopetuksen sukupolveen kuuluvien haastateltavien ( $N=6)$ elämässä sekä elämänkulun ja yhteiskunnassa osallistumisen alueet tärkeysjärjestyksessä

JÄLLEENRAKENNUS

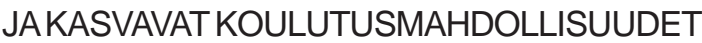

AMMATILLINEN JA VALMENTAVA ERITYISOPETUS

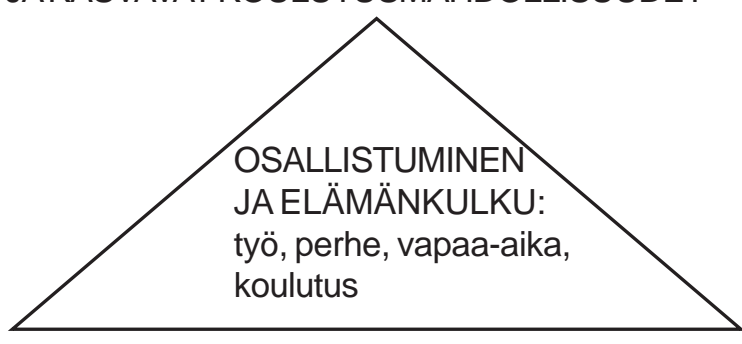

企

AMMATTI-TAITOISEN TYÖVOIMANKYSYNTÄ

KOULUTUKSEN MERKITYS:

- ammattitaito ja työ (6/6)

- ystävät (2/6)

- itsenäisen elämän taidot (2/6)

- tasavertainen tiedonsaanti (1/6)

- itsetunnon vahvistuminen (1/6)

Siirryttäessä koulutussukupolvesta toiseen koulutuksen ydinmerkitys säilyi välineellisenä. Hyvinvointiyhteiskunnassa väestön koulutustaso nousi merkittävästi, koulutusvalintoja oli aiempaa enemmän, työmarkkinat kiristyivät ja työttömyys kasvoi.

Tämän koulutussukupolven kuurot ja huonokuuloiset aikuiset kokivat koulutuksen merkitsevän ennen kaikkea tasavertaista tiedonsaantia ja osallistumista (kuvio 3). Koulutuksen ja työn yhteys heikkeni selvästi; koulutus korvasi työn. Koulutukseen liitettiin myös aiempaa useampia sosiaalisia merkityksiä.

Molempien sukupolvien haastateltavat pitivät valintamahdollisuuksiaan rajallisina. Ensimmäisen sukupolven edustajien mukaan vaihtoehtoja oli niukasti. He pitivät "nuorempien" mahdollisuuksia parempina ja monipuolisempina. Toiseen sukupolveen kuuluvien mielestä heille tarjotut tukipalvelut olivat riittämättömiä, vaikka koulutusmahdollisuuksia oli avautunut. Erityisopetuksen sukupolven kokemusten mukaan kommunikointi opettajan kanssa ja osallistuminen opinnoissa painottuivat käytännön asioihin. Vaihtoehtojen sukupolvelle kommunikointi ja aktiivinen osallistuminen olivat itsestäänselvyyksiä.

Kiinnostus jatko-opintoihin oli teema, joka osoitti sukupolvien olevan selkeästi hyvin erilaisia. Ammattiin liittyvät, tutkintotavoitteiset opinnot ja oman alan jatkokoulutus eivät kiin- nostaneet erityisopetuksen sukupolveen kuuluvia, sen sijaan heitä kiinnosti harrastusluonteinen opiskelu. Vaihtoehtojen sukupolveen kuuluvat haastateltavat olivat valmiita hankkimaan lisää muodollista koulutusta eli opiskelemaan ja päivittämään ammattitaitoaan. Yhteinen piirre molemmille koulutussukupolville oli se, että oman alan jatkokoulutusta ei oltu hankittu.

Koulutuksen kehittämiseksi haastateltavat ehdottivat vaihtoehtoja valaisevaa ammatinvalinnanohjausta, täydentävää ja valmentavaa erityisopetusta, opiskelua yleisopetuksessa ja siihen liittyvien riittävien tukitoimien järjestämistä, sujuvan vuorovaikutuksen takaamista sekä vertaisryhmän tukea.

\section{Koulutuksen merkitys tulevaisuudessa}

$\mathrm{R}$ uotsalaisten ja yhdysvaltalaisten tutkimusten mukaan kuurojen ja huonokuuloisten aikuisten koulutustaso, työllisyystilanne ja sosiaalinen asema ovat muuttuneet sukupolvesta toiseen siirryttäessä. Koulutus on ollut tärkeä tekijä sosiaalisen aseman muutoksessa. Näin ei vielä ole tapahtunut oppimisyhteiskunnan mallimaassa, Suomessa.

Toivo Nygårdin (1998) mukaan suomalainen yhteiskunta on jo 1800-luvun lopulta alkaen pyrkinyt integroimaan kuurot ja huonokuuloiset 
KUVIO 3 Koulutuksen merkitys useiden vaihtoehtojen koulutussukupolveen kuuluvien haastateltavien elämässä sekä elämänkulun ja yhteiskunnassa osallistumisen alueet tärkeysjärjestyksessä

HYVINVOINTI

JAMONET KOULUTUSVALINNAT

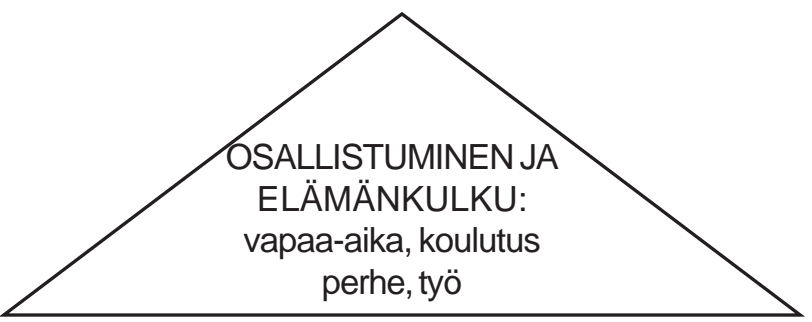

USEAT KOULUTUSVAIHTOEHDOT

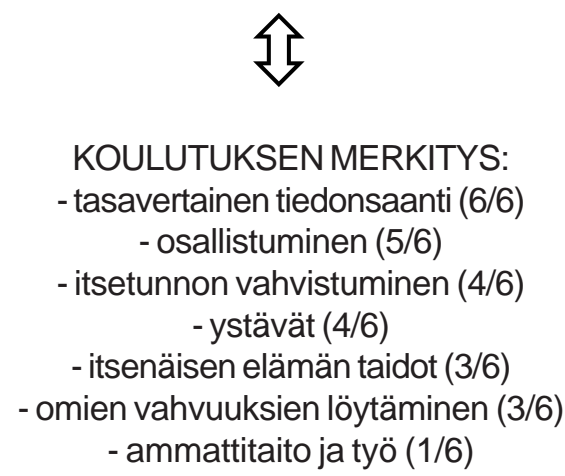

TYÖMARKKINAT JA

KASVAVA

TYÖTTÖMYYS

\author{
KOULUTUKSEN MERKITYS: \\ - tasavertainen tiedonsaanti (6/6) \\ - osallistuminen (5/6) \\ - ystävät (4/6) \\ - itsenäisen elämän taidot (3/6) \\ - ammattitaito ja työ (1/6)
}

opiskelijat osaksi kuulevaa yhteiskuntaa. Silloin motiivina oli itsenäinen toimeentulo ja köyhäinhoidon vähentäminen. Keinoina olivat puheen opetus ja puheen ymmärtäminen. Nykyiset motiivit saattavat olla samoja, mutta käytettävissä on aiempaa monipuolisempia keinoja. Yksi esimerkki on Antti Raikkeen (2005) tutkimustulos verkko-opetuksesta tasavertaisena opiskelumuotona. Lisäksi käsitys osallistumisesta on muuttunut, ja osallistujien näkökulmat ovat nousseet keskeisiksi kehittämisen välineiksi.

Todennäköisesti perusasteen jälkeisen koulutuksen tulevia haasteita ovat yleisopetuksessa tarjottavan tuen vahvistaminen osana koulutusjärjestelmän kehittämistä. Lähitulevaisuudessa koulutukseen osallistuu nuoria ja aikuisia, jotka käyttävät sisäkorvaistutetta ja joiden kuulokyky on yksilöllinen. Opetustilat on sen vuoksi suunniteltava ja rakennettava niin, että niiden akustiset ominaisuudet vastaavat myös heidän tarpeisiinsa.

Opettajilla on oltava tietoa ja taitoa antaa pedagogista tukea ryhmätilanteissa. Suunnittelun ja tutkimuksen haasteina pidän osallistujien äänen vahvistamista sekä perusasteen jälkeiseen koulutukseen osallistumisen monipuolista ja säännöllistä seurantaa.
Toistaiseksi Suomessa ei ole kerätty erityistä tukea tarvitsevilta opiskelijoilta säännöllistä palautetta ja ehdotuksia eikä käyty dialogia opiskelijoiden ja työelämän kanssa koulutuksen suunnittelusta ja toteutuksesta. Opiskelijat ovat omatoimisesti ryhtyneet jakamaan kokemuksiaan, keskustelemaan parantamisehdotuksistajajärjestämään vertaistukea (esim. Kuulonhuoltoliitto 2003).

Risto Rinteen ja Joel Kivirauman (2003a ja 2003b; ks. myös Helne 2001; Järvinen \& Jahnukainen 2001) mukaan koulutuspolitiikka ja työelämä käyvät jatkuvaa inkluusio- ja syrjäytymisdiskurssia. Koulutuksella on niukasti keinoja muuttaa yhteiskunnassa ja työelämässä vallitsevia käsityksiä kuuroista ja huonokuuloisista osallistujista. Mutta tätä tärkeämpää on kriittisesti kysyä, miten koulutus on toteuttanut omat tehtävänsä kaikille tarkoitetun oppimisyhteiskunnan edistäjänä ja käyttänyt niukatkin keinonsa vaikuttaakseen muuhun yhteiskuntaan.

Osallistujien äänen vahvistaminen koulutuksen suunnittelussa ja toteutuksessa on tärkeää opiskelun ja elinikäisen oppimisen esteiden poistamiseksi. Oppimisyhteiskuntaan osallistumisen sijaan meidän tulee tarkastella ja painottaa osallistumista oppimisyhteiskunnan kehittämiseen. 


\section{Lähteet}

Antikainen, A. (1998). Kasvatus, elämänkulku ja yhteiskunta. Helsinki: WSOY.

Antikainen, A. 2005. Koulutuksen ja yhteiskunnan reunalla. Aikuiskasvatus, 25 (3), 245246.

Davies, L. (2001). Development, democracy and deviance in contemporary sociology of education. Teoksessa J. Demaine (toim.) Sociology of Education Today. Wiltshire: Palgrave, 142-162.

Jahnukainen, M. (2001). Social exclusion and dropping out of education. Emotional and Behavioural Difficulties in Mainstream Schools, 1, 1-12.

Järvinen, T. \& Jahnukainen, M. (2001). Kuka meistä onkaan syrjäytynyt? Marginalisaation ja syrjäytymisen käsitteellistä tarkastelua. Teoksessa M. Suutari (toim.) Vallattomat marginaalit. Nuorisotutkimusverkosto, Julkaisuja 20, 125-151.

Helne, T. (2002). Syrjäytymisen yhteiskunta. Helsingin yliopisto, Valtiotieteellinen tiedekunta, Sosiaalipolitiikan laitos \& Stakes, Tutkimuksia 123.

Kasvatustieteen päivät 2005. (www.kasvatus.net/kasvatustieteenpaivat).

Kuulonhuoltoliitto. (2003). Huonokuuloinen korkeakouluopiskelija - käytänteitä ja kokemuksia.

McGaw, B. (2004). Quality education: Is the sky the limit? OECD Observer, March. (www.oecdobserver.org/news)

Nygård, T. (1998). Erilaisten historia, Marginaaliryhmät Suomessa 1800-luvulla ja 1900-luvun alussa. Atena.

OECD. (2004). Education at a Glance. (www.oecd.org/education).

Priestley, M. (2001). Disability, A life course approach. Cambridge: Polity Press.

Priestley, M. (2003). Symposium on disability and the life course. Introduction to the symposium. Disability Studies Quarterly, 23 (2), 1-5.

Raike, A. (2005). Löytäjät elokuvantajua rakentamassa, Yhteisöllinen www-palvelujen tuotanto. Taideteollinen korkeakoulu medialaboratorio. (http://elokuvantaju.uiah.fi).

Raivola, R. (2000). Esipuhe. Teoksessa R. Rai- vola (toim.) Vaikuttavuutta koulutukseen, Suomen Akatemian koulutuksen vaikuttavuusohjelman tutkimuksia. Suomen Akatemian julkaisuja 1.

Rinne, R. \& Kivirauma, J. (2003a). Koulutuksen ja syrjäytymisen muuttuva yhteys. Teoksessa R. Rinne \& J. Kivirauma (toim.) Koulutuksellista alaluokkaa etsimässä, Matala koulutus yhteiskunnallisen aseman määrittäjänä 1800-ja 1900-luvuilla. Suomen Kasvatustieteellinen Seura, Kasvatusalan tutkimuksia 18, 13-78.

Rinne, R. \& Kivirauma, J. (2003b). Oppioikeudesta kouluttautumispakkoon. Teoksessa R. Rinne \& J. Kivirauma (toim.) Koulutuksellista alaluokkaa etsimässä, Matala koulutus yhteiskunnallisen aseman määrittäjänä 1800-ja 1900-Iuvuilla. Suomen Kasvatustieteellinen Seura, Kasvatusalan tutkimuksia 18, 327-336.

Ruuskanen, E. (2005). Bovalliusten perintö, S. ja A. Bovalliuksen säätiö 1905 - 2005. Gummerus.

Salmi, E. \& Laakso, M. (2005). Maahan lämpimään, Suomen viittomakielisten historia. Kuurojen Liitto.

Sosiologia, Margins 2005. (www.joensuu.fi/sosiologia/margins2005).

Välijärvi, J. \& Kupari, P. (toim.2005). Osaaminen kestävällä pohjalla, PISA 2003 Suomessa. Koulutuksen tutkimuslaitos, OECD \& Opetusministeriö.

Kirjoitus on Elina Lehtomäen väitöskirjan lectio precursoria. Lehtomäki väitteli 22. lokakuuta Jyväskylän yliopistossa. 